University of Nebraska - Lincoln

DigitalCommons@University of Nebraska - Lincoln

Agronomy \& Horticulture - Faculty Publications

Agronomy and Horticulture Department

2010

\title{
Heterosis in Sweet Sorghum and Selection of a New Sweet Sorghum Hybrid for Use in Syrup Production in Appalachia
}

\author{
T. W. Pfeiffer \\ University of Kentucky \\ M. J. Bitzer \\ University of Kentucky \\ J. J. Toy \\ University of Nebraska-Lincoln, John.Toy@ars.usda.gov \\ Jeffrey F. Pedersen \\ University of Nebraska-Lincoln, jpedersen1@unl.edu
}

Follow this and additional works at: https://digitalcommons.unl.edu/agronomyfacpub

Part of the Agricultural Science Commons, Agriculture Commons, Agronomy and Crop Sciences Commons, Botany Commons, Horticulture Commons, Other Plant Sciences Commons, and the Plant Biology Commons

Pfeiffer, T. W.; Bitzer, M. J.; Toy, J. J.; and Pedersen, Jeffrey F., "Heterosis in Sweet Sorghum and Selection of a New Sweet Sorghum Hybrid for Use in Syrup Production in Appalachia" (2010). Agronomy \& Horticulture -- Faculty Publications. 942.

https://digitalcommons.unl.edu/agronomyfacpub/942

This Article is brought to you for free and open access by the Agronomy and Horticulture Department at DigitalCommons@University of Nebraska - Lincoln. It has been accepted for inclusion in Agronomy \& Horticulture -Faculty Publications by an authorized administrator of DigitalCommons@University of Nebraska - Lincoln. 


\title{
Heterosis in Sweet Sorghum and Selection of a New Sweet Sorghum Hybrid for Use in Syrup Production in Appalachia
}

\author{
T. W. Pfeiffer, M. J. Bitzer, J. J. Toy, and J. F. Pedersen^
}

\begin{abstract}
Although heterosis is well established in grain and forage sorghum [Sorghum bicolor (L.) Moench], reports of heterosis in sweet sorghum are limited to results from grain sorghum $x$ sweet sorghum hybrids. Recent development of cytoplasmic male-sterile sweet sorghum lines allows creation of sweet sorghum hybrids for research and industry. Male sterility may also affect allocation of photosynthate to plant parts, creating the potential to increase sugar content in stems by eliminating seed as a sink. The objectives of this study were to compare performance of $A_{3}$ cytoplasmic male-sterile lines and $A_{3}$ cytoplasmic male-sterile hybrids to fertile $B_{3}$ counterparts and to each other. $A_{3}$ cytoplasmic male-sterile 'Dale', 'Wray', 'Sugar Drip', and N100 were crossed in all combinations to their male-fertile counterparts, resulting in 20 genotypes including the male-fertile lines. The 20 genotypes were grown in a randomized complete block in 2004 and 2005 at Lexington, KY. Male-sterile hybrids and lines had higher brix than male-fertile lines. Hybrids produced greater stalk yield due to taller plants with greater stem diameter. Juice fraction and juice composition remained relatively unchanged. Only six hybrids showed positive heterosis for brix. The greater juice yield and higher sugar content of selected hybrids such as $\mathrm{A}_{3} \mathrm{~N} 100 \times$ Dale could produce more total syrup or ethanol than current pureline sweet sorghum varieties.
\end{abstract}

T.W. Pfeiffer and M.J. Bitzer [retired], 310 Plant Sciences Bldg., Dep. of Plant and Soil Sciences, Univ. of Kentucky, Lexington, KY $40546-$ 0312; J.J. Toy and J.F. Pedersen, USDA, ARS, NPA Grain, Forage, and Bioenergy Research, 314 Biochem, Univ. of Nebraska-Lincoln, Lincoln, NE 68583-0737. Joint contribution of the USDA-ARS and the Univ. of Kentucky Agric. Exp. Stn. Mention of trade names or commercial products in this article is solely for the purpose of providing specific information and does not imply recommendation or endorsement by the U.S. Department of Agriculture or the University of Kentucky. Received 1 Sept. 2009. *Corresponding author (jeff.pedersen@ars.usda.gov).

Abbreviations: GCA, general combining ability; SCA, specific combining ability.

Sorghum [Sorghum bicolor (L.) Moench] is primarily a self-pollinated species with a low but measurable frequency of outcrossing (Shertz and Dalton, 1980; Pedersen et al., 1998). Sorghum exhibits hybrid vigor, and $>95 \%$ of sorghum varieties grown for grain in the United States are $\mathrm{F}_{1}$ hybrid varieties (Axtell et al., 1999). Hybrids provide a 20 to $60 \%$ grain yield advantage (Axtell et al., 1999). While most sorghum is grown in the United States for grain or for forage, sorghum also exists as sweet sorghum types. These types have juicy stems with high sugar concentration. Instead of maximizing translocation of photosynthate into grain, sweet sorghum accumulates large amounts of sugar in stem parenchyma from anthesis until physiological maturity. In the United States, sweet sorghum has historically been and is currently used for syrup production. However, interest in sweet sorghum as a feedstock for ethanol production is increasing (Rooney et al., 2007). Unlike hybrid grain sorghum, current U.S. sweet sorghum varieties are pure-line varieties.

Published in Crop Sci. 50:1788-1794 (2010).

doi: 10.2135/cropsci2009.09.0475

Published online 1 July 2010.

(C) Crop Science Society of America | 5585 Guilford Rd., Madison, WI 53711 USA

All rights reserved. No part of this periodical may be reproduced or transmitted in any form or by any means, electronic or mechanical, including photocopying, recording, or any information storage and retrieval system, without permission in writing from the publisher. Permission for printing and for reprinting the material contained herein has been obtained by the publisher. 
Table 1. Pedigrees and synonyms for 12 sweet sorghum male-sterile hybrids and their male-sterile and fertile pureline parents (Pedersen and Toy, 1997).

\begin{tabular}{|c|c|}
\hline Pedigree & Synonym \\
\hline $\mathrm{A}_{3} \mathrm{~N} 151 \times$ 'Wray' & $\mathrm{A}_{3}$ 'Dale' $\times$ Wray \\
\hline $\mathrm{A}_{3} \mathrm{~N} 151 \times$ 'Sugar Drip' & $\mathrm{A}_{3}$ Dale $\times$ Sugar Drip \\
\hline $\mathrm{A}_{3} \mathrm{~N} 151 \times \mathrm{N} 100$ & $\mathrm{~A}_{3}$ Dale $\times \mathrm{N} 100$ \\
\hline $\mathrm{A}_{3} \mathrm{~N} 151$ & $\mathrm{~A}_{3}$ Dale \\
\hline Dale & Dale \\
\hline $\mathrm{A}_{3} \mathrm{~N} 153 \times$ Dale & $\mathrm{A}_{3}$ Wray $\times$ Dale \\
\hline $\mathrm{A}_{3} \mathrm{N153} \times$ Sugar Drip & $\mathrm{A}_{3}$ Wray $\times$ Sugar Drip \\
\hline $\mathrm{A}_{3} \mathrm{~N} 153 \times \mathrm{N} 100$ & $\mathrm{~A}_{3}$ Wray $\times$ N100 \\
\hline $\mathrm{A}_{3} \mathrm{~N} 153$ & $\mathrm{~A}_{3}$ Wray \\
\hline Wray & Wray \\
\hline $\mathrm{A}_{3} \mathrm{~N} 154 \times$ Dale & $\mathrm{A}_{3}$ Sugar Drip $\times$ Dale \\
\hline $\mathrm{A}_{3} \mathrm{~N} 154 \times$ Wray & $\mathrm{A}_{3}$ Sugar Drip $\times$ Wray \\
\hline $\mathrm{A}_{3} \mathrm{~N} 154 \times \mathrm{N} 100$ & $\mathrm{~A}_{3}$ Sugar Drip $\times$ N100 \\
\hline $\mathrm{A}_{3} \mathrm{~N} 154$ & $\mathrm{~A}_{3}$ Sugar Drip \\
\hline Sugar Drip & Sugar Drip \\
\hline $\mathrm{A}_{3} \mathrm{~N} 159 \times$ Dale & $\mathrm{A}_{3} \mathrm{~N} 100 \times$ Dale \\
\hline $\mathrm{A}_{3} \mathrm{~N} 159 \times$ Wray & $\mathrm{A}_{3} \mathrm{~N} 100 \times$ Wray \\
\hline $\mathrm{A}_{3} \mathrm{N159} \times$ Sugar Drip & $\mathrm{A}_{3} \mathrm{N100} \times$ Sugar Drip \\
\hline $\mathrm{A}_{3} \mathrm{~N} 159$ & $\mathrm{~A}_{3} \mathrm{~N} 100$ \\
\hline N100 & N100 \\
\hline
\end{tabular}

Heterosis in sorghum is expressed by earlier blooming, increased height, larger stems, greater production of grain and biomass, and larger panicle heads with a higher threshing percentage (Quinby, 1963). Earlier flowering and greater biomass from increased height and larger stems are all soughtafter traits for sweet sorghum. In comparing 24 grain sorghum hybrids with their parents, 23 had higher grain yield; however, only 16 were taller, nine bloomed earlier, and just five had greater stalk diameter than the superior parent (Kirby and Atkins, 1968). There has been little research on heterosis in sweet sorghum, although some information on characteristics valued in sweet sorghum production can be extracted from grain sorghum hybrid research. When short grain sorghum types were crossed with three tall genetically diverse sorghum accessions, midparent heterosis for grain yield was $80 \%$ with a general combining ability:specific combining ability (GCA:SCA) ratio of 3.56:1. Midparent heterosis for height was 38\% with a GCA:SCA ratio of 5.88:1 (Niehaus and Pickett, 1966). The high GCA:SCA ratios suggest the likelihood of most hybrids exhibiting heterosis for these traits.

In a set of 28 grain sorghum $\times$ sweet sorghum hybrids, 11 hybrids showed significant high-parent heterosis for green stalk yield, only two showed high-parent heterosis for percent extractable juice, and none showed significant highparent heterosis for juice brix (Selvi and Palanisamy, 1987). In a similar study involving hybrids from four grain sorghum A-lines crossed to 10 sweet sorghum restorer lines, overall heterosis was significant for plant height, green cane yield, and commercial cane sugar yield (Meshram et al., 2005).

Production of hybrid sorghum seed depends on cytoplasmic male sterility. Along with providing for economical seed production, male sterility may also affect the allocation of photosynthate to different plant parts. In rice (Oryza sativa L.), Lin and Lin (1994) concluded sterility changed the pattern of assimilate partitioning instead of reducing photosynthesis and that the stem was the most important alternative sink. Limiting seed production in sweet sorghum produces similar changes. Broadhead (1979) reported a 1-degree increase in brix following deheading before grain formation. Early deheading of sweet sorghum is recommended, as stem brix decreases from 19 degrees when deheaded at early seed stage to 15 degrees when deheaded in the hard-dough stage of seed development (Bitzer and Fox, 1994). Fortmeier and Schubert (1995) measured a constant soluble carbohydrate concentration in the stems of sweet sorghum male-sterile plants compared with a $20 \%$ decline from $34 \mathrm{~d}$ after anthesis until maturity in fertile sweet sorghum plants. Karper and Quinby (1963) reported an increase in stem sugar from 15 to $17 \%$ when male-sterile plants did not set seed vs. when cross-pollination and seed set was allowed. Although nonsignificant, Clark et al. (1984) reported total stem sugar at 109 when expressed as (sterile/fertile) $\times 100$ for three sterile-fertile sorghum pairs. There is thus the potential for male sterility to positively influence brix in sweet sorghum stems.

Hybrid sorghum is produced using the $A_{1}$ cytoplasmic male-sterility system because growers and breeders are familiar with it, and numerous lines restore fertility in the $A_{1}$ system, making production of fertile hybrids possible. However, other cytoplasmic male-sterility systems are available, and one of them, $A_{3}$, could be particularly useful for production of male-sterile hybrids because few lines have been shown to restore fertility in $\mathrm{A}_{3}$ cytoplasm (Bosques-Vega et al., 1989; Torres-Cardona et al., 1990).

The objectives of this study were to: (i) compare performance of $\mathrm{A}_{3}$ cytoplasmic male-sterile lines to iso-cytoplasmic fertile $\mathrm{B}_{3}$ lines, (ii) compare performance of $\mathrm{A}_{3}$ cytoplasmic male-sterile hybrids with fertile $\mathrm{B}_{3}$ versions of their parental lines, and (iii) compare performance of $\mathrm{A}_{3}$ cytoplasmic male-sterile hybrids to $\mathrm{A}_{3}$ cytoplasmic male-sterile versions of their parental lines.

\section{MATERIALS AND METHODS Development of Genetic Material}

The sweet sorghum varieties 'Dale' (Broadhead and Coleman, 1973), 'Wray' (Broadhead et al., 1981), and 'Sugar Drip' (McCall et al., 1936), and the sweet sorghum germplasm N100 (Gorz et al., 1990) were previously male-sterilized in $\mathrm{A}_{3}$ cytoplasm (Pedersen and Toy, 1997). The male-sterile versions of these lines were crossed in all combinations to the male-fertile versions of these same lines. All four male-fertile lines are male-sterility maintainers or $\mathrm{B}_{3}$-lines to $\mathrm{A}_{3}$ cytoplasm (none restore fertility), so the resulting hybrids were all male-sterile. Seed of the male-fertile lines were also produced, resulting in the 20 genotypes used in this study (Table 1). 


\section{Field Experiment}

The experiment was grown on a Maury silt loam soil (fine, mixed, semiactive, mesic Typic Paleudalf) in 2004 and 2005 at the University of Kentucky research farm, Lexington, KY (lat $38^{\circ} \mathrm{N}$ ). The 20 genotypes were planted in a randomized complete block design with four replications on 11 May both years. Plots were three rows wide, $6 \mathrm{~m}$ long, with $0.76-\mathrm{m}$ row spacing. Planting rate was 12 seeds $\mathrm{m}^{-1}$. Weeds were controlled using preplant-incorporated and postemergence-applied herbicides along with an herbicide safener seed treatment as recommended for grain sorghum in Kentucky (Martin and Green, 2003). Data were collected on the center of the three rows in a plot. Nitrogen was applied $30 \mathrm{~d}$ after planting at approximately growth stage 2 (Vanderlip, 1993) at $35 \mathrm{~kg} \mathrm{ha}^{-1}$ as recommended for sweet sorghum for syrup (Bitzer, 1994). Before anthesis, as the flower head was emerging from the flag leaf, the flower head was bagged with a sorghum pollinating bag on 20 plants in the center row of the plot. Plants were bagged on all plots, both male-fertile and malesterile entries, to maintain sterility and to base the comparison on bagged plants of both the sterile and fertile entries (Broadhead, 1979). All data except for lodging and disease ratings were collected from these bagged plants. Lodging and disease ratings were assigned on a whole-plot visual evaluation.

Data were collected for heading date (date on which the heads of 20 plants were bagged before pollen shed), and lodging (score 5 to 1 , with $5=$ no lodging to $1=>75 \%$ plants lodged). Plots were harvested when the seeds on the malefertile pure-line varieties were at the hard-dough stage, stage 8 (Vanderlip, 1993). Twelve plants were harvested per plot. Panicles were removed. Plant height (cutting point to point of panicle removal, $\mathrm{cm}$ ) and stem diameter (fourth internode from the cutting point, $\mathrm{mm}$ ) were measured on two of the 12 plants, and the mean of the two measurements was analyzed. Leaves were stripped from the plant, and the weight $(\mathrm{kg})$ of 12 stems was recorded. The stripped stems were crushed with a three-roller horizontal sweet sorghum mill, and the juice was collected and weighed $(\mathrm{kg})$. Juice brix (\% sugar + starch) was measured with a handheld manual refractometer for brix range 0 to $30 \%$. Sugar yield was calculated as $\mathrm{kg}$ juice $\times \%$ brix.

\section{Statistical Analysis}

The data were analyzed by Proc MIXED of SAS (Statistical Analysis System version 9.1, SAS Institute, Cary, NC) with year, replication, and year(replication) included in the RANDOM statement and type and entry(type) included in the MODEL statement, with type being $\mathrm{B}_{3}$ line, $\mathrm{A}_{3}$ line, or hybrid. For each trait, homogeneity of error variance across years was tested using a Levene's test, and models with heterogeneous variance were fitted by inclusion of a REPEATED statement with GROUP $=$ year. Least squares means were estimated and single degree of freedom comparisons made among LSMEANS by inclusion of the DIFF option. Comparisons were declared significant at $P=0.05$. Single degree of freedom comparisons of $\mathrm{B}_{3}$ lines vs. $\mathrm{A}_{3}$ lines, $\mathrm{A}_{3}$ hybrids vs. $\mathrm{A}_{3}$ lines, and $\mathrm{A}_{3}$ hybrids vs. $B_{3}$ lines are reported. High-parent heterosis (hybrid
Table 2. Significance levels of genotype and year plus the year means for 12 sweet sorghum male-sterile hybrids and their male-sterile and fertile pure-line parents, 2004 and 2005, Lexington, KY.

\begin{tabular}{|c|c|c|c|c|}
\hline Trait & Genotype & Year & 2004 & 2005 \\
\hline Stalk yield $\left(\right.$ g plant $^{-1}$ ) & $\star \star$ & $N S^{\dagger}$ & 556 & 563 \\
\hline Juice yield (g plant $\left.{ }^{-1}\right)$ & ** & $\star \star *$ & 250 & 216 \\
\hline $\operatorname{Brix}(\%)$ & ** & ** & 19.1 & 19.5 \\
\hline Height (cm) & ** & NS & 251 & 259 \\
\hline Stem diameter (mm) & * & NS & 20 & 20 \\
\hline Lodging (score) $)^{\ddagger}$ & * & * & 4.6 & 3.5 \\
\hline Maturity (d from planting to heading) & ** & $\star *$ & 88 & 92 \\
\hline
\end{tabular}

${ }^{*}$ Significant at $P \leq 0.05$.

${ }^{*}$ Significant at $P \leq 0.01$

${ }^{\dagger} \mathrm{NS}$, not significant at $P \leq 0.05$.

₹Score 5 to $1: 5=$ no lodging to $1=>75 \%$ plants lodged.

value - value of the superior parent [either $\mathrm{A}_{3}$ female line or $\mathrm{B}_{3}$ male line]) was calculated for each hybrid for each trait.

\section{RESULTS}

The genotypes (12 male-sterile hybrids, 4 male-sterile lines, and 4 male-fertile lines) exhibited significant variation for every measured trait (Table 2). The environment in 2004 produced a greater juice yield than the environment in 2005. Conversely, brix was higher in 2005 than in 2004. While plant growth (stalk height and diameter) did not differ in the $2 \mathrm{yr}$, the plants lodged significantly more in 2005 than in 2004. Although planted on 11 May in each year, the sorghum flowered $4 \mathrm{~d}$ earlier in 2005 .

The male-sterile hybrids produced $18 \%$ more biomass and $20 \%$ more juice than the male-sterile lines as well as $17 \%$ more biomass and 9\% more juice than the fertile lines (Tables 3 and 4). Compared with the male-sterile lines, the greater biomass of the hybrids resulted from both $22-\mathrm{cm}$ taller plants and $1.2-\mathrm{mm}$ greater stalk diameter (Table 5). The juice yield and stalk yield did not differ significantly between the fertile and sterile parental lines. The juice from the male-sterile hybrids and lines had a higher brix than the juice from the fertile lines. The hybrids produced 20\% more sugar yield than the male-sterile lines and 14\% more than the fertile lines. The fertile lines lodged more than the sterile lines by 0.4 unit score due to both $16-\mathrm{cm}$ taller plants and the increased leverage on the stem exerted by the seed weight of the fertile panicle. While the hybrids flowered at similar dates to the $A_{3}$ female lines, the $A_{3}$ female lines flowered $2.5 \mathrm{~d}$ earlier than the $\mathrm{B}_{3}$ male lines, and the $\mathrm{A}_{3}$ hybrids flowered $3.7 \mathrm{~d}$ earlier than the $\mathrm{B}_{3}$ male lines.

High-parent heterosis was significant for at least one hybrid combination for each of the traits except lodging (Tables 3-5). Six of the 12 hybrids showed high-parent heterosis for stalk yield (Table 4). These six hybrids averaged $17 \%$ heterosis for stalk yield, with $\mathrm{A}_{3}$ Dale $\times$ N100 exhibiting $28 \%$ heterosis. No hybrids with $\mathrm{A}_{3}$ Sugar Drip as the female parent exhibited high-parent heterosis for stalk yield. Three hybrids showed significant high-parent heterosis for 
Table 3. Comparisons of sugar traits of sweet sorghum $B_{3}$ lines, $A_{3}$ lines, and hybrids grown at Lexington, KY, in 2004 and 2005.

\begin{tabular}{|c|c|c|c|c|c|c|c|c|c|c|}
\hline \multirow[b]{2}{*}{$\begin{array}{l}\text { Group } \\
\text { or line }\end{array}$} & \multicolumn{2}{|c|}{ Juice yield } & \multicolumn{2}{|c|}{ Juice brix } & \multicolumn{2}{|c|}{ Sugar yield } & \multicolumn{4}{|c|}{ Differences between groups or lines ${ }^{\dagger}$} \\
\hline & Mean $\ddagger$ & $\begin{array}{l}\text { High-parent } \\
\text { heterosis }^{\S}\end{array}$ & Mean ${ }^{\ddagger}$ & $\begin{array}{c}\text { High-parent } \\
\text { heterosis }\end{array}$ & Mean $\ddagger$ & $\begin{array}{c}\text { High-parent } \\
\text { heterosis }\end{array}$ & Comparison & $\begin{array}{l}\text { Juice } \\
\text { yield }\end{array}$ & $\begin{array}{l}\text { Juice } \\
\text { brix }\end{array}$ & $\begin{array}{l}\text { Sugar } \\
\text { yield }\end{array}$ \\
\hline & $\longrightarrow$ & 9 plant $^{-1}$ & 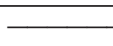 & $-\%$ & $-\mathrm{g}$ & plant ${ }^{-1}$ & & g plant $^{-1}$ & $\%$ & g plant $^{-1}$ \\
\hline $\mathrm{B}_{3}$ lines & 220 & & 19.1 & & 42 & & $\mathrm{~B}_{3}$ lines- $\mathrm{A}_{3}$ lines & 14 & $-0.5^{*}$ & 2 \\
\hline$A_{3}$ lines & 206 & & 19.6 & & 40 & & Hybrids- $\mathrm{A}_{3}$ lines & $40^{*}$ & -0.1 & $8^{*}$ \\
\hline Hybrids & 246 & & 19.5 & & 48 & & Hybrids- $\mathrm{B}_{3}$ lines & $20^{*}$ & $0.4^{\star}$ & $6^{\star}$ \\
\hline $\mathrm{A}_{3}$ 'Dale' × 'Wray' & 227 & $34^{*}$ & 20.0 & -0.06 & 45 & $5^{\star}$ & & & & \\
\hline $\mathrm{A}_{3}$ Dale $\times$ 'Sugar Drip' & 261 & 23 & 19.4 & -0.02 & 51 & $7^{*}$ & & & & \\
\hline $\mathrm{A}_{3}$ Dale $\times \mathrm{N} 100$ & 242 & $55^{\star}$ & 19.1 & -0.05 & 46 & $10^{*}$ & & & & \\
\hline$A_{3}$ Dale & 186 & & 19.8 & & 36 & & & & & \\
\hline Dale & 261 & & 18.4 & & 48 & & $\mathrm{~B}_{3}$ Dale- $\mathrm{A}_{3}$ Dale & $75^{\star}$ & $-1.4^{*}$ & $12^{*}$ \\
\hline $\mathrm{A}_{3}$ Wray $\times$ Dale & 269 & 8 & 20.2 & -0.03 & 54 & $6^{\star}$ & & & & \\
\hline $\mathrm{A}_{3}^{3}$ Wray $\times$ Sugar Drip & 238 & 0 & 19.5 & -1.0 & 46 & 2 & & & & \\
\hline $\mathrm{A}_{3}$ Wray $\times$ N100 & 230 & 24 & 19.3 & -1.2 & 44 & 2 & & & & \\
\hline $\mathrm{A}_{3}$ Wray & 206 & & 20.5 & & 42 & & & & & \\
\hline Wray & 193 & & 20.7 & & 40 & & $\mathrm{~B}_{3}$ Wray-A $\mathrm{A}_{3}$ Wray & -13 & 0.2 & -2 \\
\hline $\mathrm{A}_{3}$ Sugar Drip $\times$ Dale & 258 & -3 & 19.8 & 0.5 & 51 & 3 & & & & \\
\hline $\mathrm{A}_{3}$ Sugar Drip $\times$ Wray & 219 & -30 & 19.5 & -1.1 & 43 & -5 & & & & \\
\hline $\mathrm{A}_{3}$ Sugar Drip $\times$ N100 & 251 & 2 & 19.3 & 0.1 & 48 & 0 & & & & \\
\hline $\mathrm{A}_{3}$ Sugar Drip & 249 & & 19.3 & & 48 & & & & & \\
\hline Sugar Drip & 238 & & 18.7 & & 44 & & $\mathrm{~B}_{3}$ Sugar Drip- $\mathrm{A}_{3}$ Sugar Drip & -11 & -0.6 & -4 \\
\hline $\mathrm{A}_{3} \mathrm{~N} 100 \times$ Dale & 266 & 5 & 19.7 & $0.7^{\star}$ & 53 & $5^{\star}$ & & & & \\
\hline $\mathrm{A}_{3} \mathrm{~N} 100 \times$ Wray & 219 & 26 & 19.2 & -1.5 & 42 & 2 & & & & \\
\hline $\mathrm{A}_{3} \mathrm{~N} 100 \times$ Sugar Drip & 274 & $38^{*}$ & 19.2 & 0.2 & 52 & $8^{*}$ & & & & \\
\hline $\mathrm{A}_{3} \mathrm{~N} 100$ & 185 & & 19.0 & & 35 & & & & & \\
\hline N100 & 187 & & 18.6 & & 35 & & $\mathrm{~B}_{3} \mathrm{~N} 100-\mathrm{A}_{3} \mathrm{~N} 100$ & 2 & -0.4 & 0 \\
\hline
\end{tabular}

*Significant at $P \leq 0.05$.

tSignificance determined using a two-tailed $t$ test of least squares means.

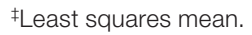

$\S$ Significance of high-parent heterosis was determined using a one-tailed $t$ test of least squares means.

juice yield, while only the hybrid $\mathrm{A}_{3} \mathrm{~N} 100 \times$ Dale exhibited high-parent heterosis for juice brix (Table 3). Combining these two traits produced six hybrids exhibiting high-parent heterosis for sugar yield (Table 3). Mirroring stalk yield heterosis, these six hybrids averaged $16 \%$ heterosis for sugar yield, with $\mathrm{A}_{3}$ Dale $\times$ N100 exhibiting $28 \%$ heterosis.

\section{DISCUSSION}

Sorghum with $>8 \%$ brix in the juice of the stem is generally defined as sweet sorghum. The stems have to be juicy ( $d$ recessive to $D$ ) instead of dry and sweet ( $x$ recessive to $X$ ) instead of nonsweet (Rooney, 2000). Forage sorghum also has sweet, juicy stems to increase palatability for livestock, but the growth habit is different from sweet sorghum used for syrup. Sweet sorghum varieties used for syrup are tall (approximately $2 \mathrm{~m}$ ) with thick stems (approximately $15 \mathrm{~mm}$ ), while forage sorghum is shorter with much finer stems. While some grain sorghum varieties (e.g., Tx623) have sweet, juicy stems, the grain sorghum varieties are shorter (usually having recessive alleles at three of the four Dw genes) than sweet sorghum varieties (having recessive alleles at two or one $D w$ genes). Sweet sorghum varieties also differ from grain sorghum in that they have two sinks for photosynthate, the seeds and the stems, while grain sorghum has been selected as having one primary sink for photosynthate, the grain. Most hybrid research involving sweet sorghum has utilized one grain sorghum parent, the female parent with cytoplasmic male sterility (e.g., ATx623; FAO, 1994).

The conversion of four sweet sorghum varieties to cytoplasmic male-sterile lines allowed this initial investigation into the hybrid vigor for sweet sorghum characteristics in an entirely sweet sorghum background. Sweet sorghum for syrup is grown primarily in the southeastern United States, although it extends north and west to Wisconsin, Iowa, and Minnesota, with up to 12,140 ha (30,000 acres) being grown for syrup production (National Sweet Sorghum Producers and Processors Association, 2009). Sweet sorghum for ethanol can be grown in diverse and widespread areas of the United States. Desirable attributes of sweet sorghum varieties used for syrup production include a high yield of medium to large stalks, low lodging, and a high percentage of extractable juice with high total soluble solids (brix) content, mostly sugars. These attributes will also be desirable for using sweet sorghum as a bioenergy crop for ethanol production.

Hybrids will be useful for increasing biomass yields of sweet sorghum (Table 4). Hybrids produced a greater stalk yield due to taller plants with greater stem diameter. This greater stalk yield translated into a greater juice amount even though there was no hybrid vigor for juice fraction. The greater juice yield and higher brix of the hybrids will 
Table 4. Stalk yield and maturity of sweet sorghum $B_{3}$ lines, $A_{3}$ lines, and hybrids grown at Lexington, KY, in 2004 and 2005.

\begin{tabular}{|c|c|c|c|c|c|c|c|}
\hline \multirow{2}{*}{$\begin{array}{l}\text { Group } \\
\text { or line }\end{array}$} & \multicolumn{2}{|r|}{ Stalk yield } & \multicolumn{2}{|r|}{ Maturity ${ }^{\dagger}$} & \multicolumn{3}{|c|}{ Differences between groups or lines ${ }^{\ddagger}$} \\
\hline & Mean§ & High-parent heterosis? & Mean§ & High-parent heterosis & Comparison & Stalk yield & $\overline{\text { Maturity }}$ \\
\hline & $\overline{2}$ & g plant ${ }^{-1}$ & $\longrightarrow$ & $\mathrm{d}=$ & & g plant $^{-1}$ & $d$ \\
\hline $\mathrm{B}_{3}$ lines & 508 & & 93.0 & & $\mathrm{~B}_{3}$ lines- $\mathrm{A}_{3}$ lines & 7 & $2.5^{\star}$ \\
\hline $\mathrm{A}_{3}$ lines & 501 & & 90.5 & & Hybrids- $\mathrm{A}_{3}$ lines & $94^{*}$ & -1.2 \\
\hline Hybrids & 595 & & 89.3 & & Hybrids- $\mathrm{B}_{3}$ lines & $87^{*}$ & $-3.7^{\star}$ \\
\hline$A_{3}$ Dale $\times$ Wray & 560 & 60 & 88.4 & -5.6 & & & \\
\hline$A_{3}$ Dale $\times$ Sugar Drip & 607 & $76^{*}$ & 94.0 & -0.6 & & & \\
\hline $\mathrm{A}_{3}$ Dale $\times \mathrm{N} 100$ & 591 & $131^{*}$ & 88.5 & -5.6 & & & \\
\hline $\mathrm{A}_{3}$ Dale & 460 & & 94.0 & & & & \\
\hline Dale & 576 & & 95.2 & & $\mathrm{~B}_{3}$ Dale- $\mathrm{A}_{3}$ Dale & $116^{*}$ & 1.1 \\
\hline $\mathrm{A}_{3}$ Wray $\times$ Dale & 643 & $67^{*}$ & 90.4 & -4.8 & & & \\
\hline $\mathrm{A}_{3}$ Wray $\times$ Sugar Drip & 623 & $92^{*}$ & 89.8 & -4.8 & & & \\
\hline $\mathrm{A}_{3}$ Wray $\times \mathrm{N} 100$ & 526 & 27 & 86.8 & -3.2 & & & \\
\hline$A_{3}$ Wray & 499 & & 87.2 & & & & \\
\hline Wray & 500 & & 92.4 & & $\mathrm{~B}_{3}$ Wray-A $\mathrm{A}_{3}$ Wray & 1 & $5.2^{*}$ \\
\hline $\mathrm{A}_{3}$ Sugar Drip $\times$ Dale & 618 & 42 & 95.0 & 0.2 & & & \\
\hline $\mathrm{A}_{3}$ Sugar Drip $\times$ Wray & 584 & 19 & 86.4 & -7.7 & & & \\
\hline $\mathrm{A}_{3}$ Sugar Drip $\times$ N100 & 580 & 15 & 88.0 & -6.0 & & & \\
\hline$A_{3}$ Sugar Drip & 565 & & 94.1 & & & & \\
\hline Sugar Drip & 531 & & 94.6 & & $\mathrm{~B}_{3}$ Sugar Drip- $\mathrm{A}_{3}$ Sugar Drip & -34 & 0.5 \\
\hline $\mathrm{A}_{3} \mathrm{~N} 100 \times$ Dale & 661 & $85^{\star}$ & 90.5 & -4.7 & & & \\
\hline $\mathrm{A}_{3} \mathrm{~N} 100 \times$ Wray & 543 & 43 & 85.2 & -7.1 & & & \\
\hline $\mathrm{A}_{3} \mathrm{N100} \times$ Sugar Drip & 599 & $67^{*}$ & 88.8 & -5.8 & & & \\
\hline $\mathrm{A}_{3} \mathrm{~N} 100$ & 480 & & 86.7 & & & & \\
\hline N100 & 426 & & 90.0 & & $\mathrm{~B}_{3} \mathrm{~N} 100-\mathrm{A}_{3} \mathrm{~N} 100$ & -54 & $3.2^{*}$ \\
\hline
\end{tabular}

*Significant at $P \leq 0.05$.

tDays from planting to heading.

¥Significance determined using a two-tailed $t$ test of least squares means.

§east squares mean.

"Significance of high-parent heterosis was determined using a one-tailed $t$ test of least squares means.

produce more total syrup or ethanol than current pure-line sweet sorghum varieties, represented by the $\mathrm{B}_{3}$ lines in this study (Table 3). These results from hybrid varieties have also been seen in crosses between sweet, juicy grain sorghum and sweet sorghum. For example, compared with the best performing sweet sorghum pure-line variety the Chinese hybrid Shennong No. 2 (ATx623 × 'Roma') produced 4\% more biomass per hectare with no change in juice fraction or brix (FAO, 1994). Similarly Selvi and Palanisamy (1987) reported 19 of 28 grain sorghum $\times$ sweet sorghum hybrids with positive high-parent heterosis for stalk yield. For brix, however, six hybrids showed positive heterosis while 22 of the 28 hybrids showed negative heterosis. Heterosis manifests itself as greater growth and biomass production, but the juice fraction and juice composition remain relatively unchanged.

A notable spin-off of the basic research on sweet sorghum heterosis described above was the release of a male-sterile sweet sorghum hybrid for use in syrup production. Based on the high-parent heterosis exhibited by several of the hybrids in this experiment, in 2006 we conducted further agronomic tests of $A_{3}$ Wray $\times$ Dale, $A_{3}$ Sugar Drip $\times$ Dale, $A_{3}$ N100 $\times$ Dale, and $A_{3}$ N100 $\times$ Sugar Drip at three Kentucky locations using $A_{3}$ Dale as a check. Bagging of panicles was unnecessary since no entries produced fertile pollen. Combined across five environments in 2004, 2005, and 2006, $\mathrm{A}_{3}$ N100 $\times$ Dale and $A_{3}$ Sugar Drip $\times$ Dale produced $24 \%$ more stalk and juice weight with equal brix, juice percentage, and lodging compared with $A_{3}$ Dale. $A_{3} \mathrm{~N} 100 \times$ Dale flowered 5 d earlier than $A_{3}$ Dale and $A_{3}$ Sugar Drip $\times$ Dale. In 2007 the Kentucky Agricultural Experiment Station, cooperating with the USDA at the University of Nebraska, released A $_{3}$ N100 $\times$ Dale as the male-sterile hybrid variety KN-Morris. This hybrid is intended for sweet sorghum syrup production in the primary syrup production region centered in Kentucky. It is recognized that male-sterile condition of this hybrid increases its susceptibility to sorghum ergot caused by Claviceps africana Frederikson, Mantle \& De Milliano (Bandyopadhyay et al., 1998), but occurrence of this pathogen has not yet been documented in this region. The name KNMorris highlights the cooperative development of the hybrid between Kentucky $(\mathrm{K})$ and Nebraska $(\mathrm{N})$ and recognizes Dr. Morris Bitzer, the long-term executive secretary of the National Sweet Sorghum Producers and Processors Association, a sweet sorghum production expert, and a tireless promoter of the sweet sorghum syrup industry.

\section{References}

Axtell, J., I. Kapran, Y. Ibrahim, G. Ejeta, and D.J. Andrews. 1999. Heterosis in sorghum and pearl millet. p. 375-386. In J.G. Coors and S. Pandey (ed.) Genetics and exploitation of heterosis in crops. ASA, Madison, WI. 
Table 5. Stalk height, diameter, and lodging of sweet sorghum $B_{3}$ lines, $A_{3}$ lines, and hybrids grown at Lexington, KY in 2004 and 2005.

\begin{tabular}{|c|c|c|c|c|c|c|c|c|c|c|}
\hline \multirow[b]{2}{*}{$\begin{array}{l}\text { Group } \\
\text { or line }\end{array}$} & \multicolumn{2}{|c|}{ Stalk height } & \multicolumn{2}{|c|}{ Stalk diameter } & \multicolumn{2}{|c|}{ Lodging $^{\dagger}$} & \multicolumn{4}{|c|}{ Differences between groups or lines ${ }^{\ddagger}$} \\
\hline & Mean§ & $\begin{array}{l}\text { High-parent } \\
\text { heterosis" }\end{array}$ & Mean§ & $\begin{array}{c}\text { High-parent } \\
\text { heterosis }\end{array}$ & Mean§ & $\begin{array}{l}\text { High-parent } \\
\text { heterosis }\end{array}$ & Comparison & $\begin{array}{c}\text { Stalk } \\
\text { height }\end{array}$ & $\begin{array}{l}\text { Stalk } \\
\text { diam. }\end{array}$ & Lodging \\
\hline & $\longrightarrow$ & $-\mathrm{cm}-$ & $\longrightarrow$ & $-\mathrm{mm} \longrightarrow$ & $\longrightarrow$ & score - & & $\mathrm{cm}$ & $\mathrm{mm}$ & score \\
\hline $\mathrm{B}_{3}$ lines & 255 & & 19.7 & & 3.9 & & $\mathrm{~B}_{3}$ lines- $\mathrm{A}_{3}$ lines & $16^{\star}$ & 0.5 & $-0.4^{*}$ \\
\hline$A_{3}$ lines & 239 & & 19.2 & & 4.3 & & Hybrids- $\mathrm{A}_{3}$ lines & $22^{*}$ & $1.2^{*}$ & -0.2 \\
\hline Hybrids & 261 & & 20.4 & & 4.1 & & Hybrids- $\mathrm{B}_{3}$ lines & 6 & 0.7 & 0.2 \\
\hline$A_{3}$ 'Dale' $\times$ 'Wray' & 275 & 2 & 18.4 & -1.5 & 3.5 & -0.8 & & & & \\
\hline $\mathrm{A}_{3}$ Dale $\times$ 'Sugar Drip' & 258 & 0 & 19.9 & -0.7 & 4.1 & 0.2 & & & & \\
\hline $\mathrm{A}_{3}$ Dale $\times \mathrm{N} 100$ & 242 & 0 & 21.6 & $3.0^{\star}$ & 3.9 & -0.2 & & & & \\
\hline $\mathrm{A}_{3}$ Dale & 242 & & 18.6 & & 3.8 & & & & & \\
\hline Dale & 278 & & 20.1 & & 3.3 & & $\mathrm{~B}_{3}$ Dale- $\mathrm{A}_{3}$ Dale & $36^{*}$ & 1.5 & -0.5 \\
\hline $\mathrm{A}_{3}$ Wray $\times$ Dale & 283 & 5 & 20.3 & 0.2 & 3.4 & -1.0 & & & & \\
\hline $\mathrm{A}_{3}$ Wray $\times$ Sugar Drip & 277 & 14 & 20.8 & 0.2 & 4.1 & -0.3 & & & & \\
\hline $\mathrm{A}_{3}$ Wray $\times$ N100 & 261 & -2 & 18.9 & -0.8 & 4.3 & -0.1 & & & & \\
\hline $\mathrm{A}_{3}$ Wray & 263 & & 19.8 & & 4.4 & & & & & \\
\hline Wray & 273 & & 19.9 & & 4.3 & & $\mathrm{~B}_{3}$ Wray-A $\mathrm{A}_{3}$ Wray & 10 & 0.2 & 0.1 \\
\hline $\mathrm{A}_{3}$ Sugar Drip $\times$ Dale & 266 & -12 & 20.5 & 0.4 & 4.5 & 0.2 & & & & \\
\hline $\mathrm{A}_{3}$ Sugar Drip $\times$ Wray & 264 & -9 & 20.1 & 0.1 & 4.1 & -0.2 & & & & \\
\hline $\mathrm{A}_{3}$ Sugar Drip $\times$ N100 & 248 & 1 & 21.1 & $2.2^{*}$ & 4.4 & 0.1 & & & & \\
\hline $\mathrm{A}_{3}$ Sugar Drip & 247 & & 18.9 & & 4.3 & & & & & \\
\hline Sugar Drip & 258 & & 20.6 & & 3.9 & & $\mathrm{~B}_{3}$ Sugar Drip- $\mathrm{A}_{3}$ Sugar Drip & 11 & 1.7 & -0.4 \\
\hline $\mathrm{A}_{3} \mathrm{N100} \times$ Dale & 257 & $-21^{*}$ & 21.4 & 1.3 & 3.9 & -0.7 & & & & \\
\hline $\mathrm{A}_{3} \mathrm{~N} 100 \times$ Wray & 260 & -13 & 20.3 & 0.4 & 4.1 & -0.5 & & & & \\
\hline $\mathrm{A}_{3} \mathrm{~N} 100 \times$ Sugar Drip & 241 & -17 & 21.5 & 0.9 & 4.5 & -0.1 & & & & \\
\hline $\mathrm{A}_{3} \mathrm{~N} 100$ & 205 & & 19.7 & & 4.6 & & & & & \\
\hline N100 & 212 & & 18.2 & & 4.1 & & $\mathrm{~B}_{3} \mathrm{~N} 100-\mathrm{A}_{3} \mathrm{~N} 100$ & 7 & -1.5 & -0.5 \\
\hline
\end{tabular}

*Significant at $P \leq 0.05$.

tScore 5 to 1: 5, no lodging to 1, >75\% plants lodged.

‡Significance determined using a two-tailed $t$ test of least squares means.

§Least squares mean.

"Significance of high-parent heterosis was determined using a one-tailed $t$ test of least squares means.

Bandyopadhyay, R., D.E. Frederickson, N.W. McLaren, G.N. Odvody, and M.J. Ryley. 1998. Ergot: A new disease threat to sorghum in the Americas and Australia. Plant Dis. 82:356-367.

Bitzer, M.J. 1994. Production of sweet sorghum for syrup in Kentucky. Univ. of Kentucky Coop. Ext. Serv. AGR 122. Kentucky Agric. Exp. Stn., Lexington.

Bitzer, M.J., and J.D. Fox. 1994. Processing sweet sorghum for syrup in Kentucky. Univ. of Kentucky Coop. Ext. Serv. AGR 123. Kentucky Agric. Exp. Stn., Lexington.

Bosques-Vega, A., A. Sotomayor-Rios, S. Torres-Cardona, H.R. Perrerly, and K.F. Schertz. 1989. Maintainer and restorer reactions with $\mathrm{B}_{1}, \mathrm{~A}_{2}$, and $\mathrm{A}_{3}$ cytoplasm of lines from the sorghum conversion program. MP-1676. Texas Agric. Exp. Stn., Texas A\&M Univ., College Station.

Broadhead, D.M. 1979. Influence of bagging sweet sorghum panicles on stalk yield and juice quality. Crop Sci. 19:195-196.

Broadhead, D.M., and O.H. Coleman. 1973. Registration of Dale sweet sorghum. Crop Sci. 13:776.

Broadhead, D.M., K.C. Freeman, and N. Zummo. 1981. Registration of Wray sweet sorghum. Crop Sci. 21:987.

Clark, J.W., R.A. Creelman, and F.R. Miller. 1984. Impacts of sterility on plant characters and fermentable carbohydrates in sorghum. PR-4192. Texas Agric. Exp. Stn., Texas A\&M Univ., College Station.

FAO. 1994. Breeding and cultivation of sweet sorghum. Chapter 2. In L. Nan et al. (ed.) Integrated energy systems in China-The cold Northeastern region experience. Available at http://www. fao.org/docrep/T4470E/t4470e05.htm (verified 6 May 2010). Corporate Document Repository, FAO, Rome.

Fortmeier, R., and S. Schubert. 1995. Storage of non-structural carbohydrates in sweet sorghum [Sorghum bicolor (L) Moench]:
Comparison of sterile and fertile lines. J. Agron. Crop Sci. 175:189-193.

Gorz, H.J., F.A. Haskins, and B.E. Johnson. 1990. Registration of 15 germplasm lines of grain sorghum and sweet sorghum. Crop Sci. 30:762-763.

Karper, R.E., and J.R. Quinby. 1963. Sugary endosperm in sorghum. J. Hered. 54:121-126.

Kirby, J.S., and R.E. Atkins. 1968. Heterotic response for vegetative and mature plant characters in grain sorghum, Sorghum bicolor (L.) Moench. Crop Sci. 8:335-339.

Lin, J.Y., and J.L. Lin. 1994. Post-heading partitioning dynamics of total nonstructural carbohydrates in rice plants as influenced by sink manipulation. J. Agric. Assoc. China 165:53-59.

Martin, J.R., and J.D. Green. 2003. Weed control recommendations for Kentucky farm crops-2003. Univ. of Kentucky Coop. Ext. Serv. AGR 6. Kentucky Agric. Exp. Stn., Lexington.

McCall, M.A., H.B. Brown, J.A. Clark, E.F. Gaines, H.K. Hayes, and W.J. Morse. 1936. Agronomic affairs, minutes of the twentyninth annual meeting of the society: Varietal standardization and registration. J. Am. Soc. Agron. 28:1027-1028.

Meshram, M.P., S.B. Atale, R.D. Murumkar, and P.B. Raut. 2005. Heterosis and heterobeltiosis studies in sweet sorghum. Ann. Plant Phys. 19:96-98.

National Sweet Sorghum Producers and Processors Association. 2009 Sweet sorghum FAQs. Available at http://www.ca.uky.edu/ nssppa/sorghumfaqs.html (verified 6 May 2010). Natl. Sweet Sorghum Producers and Processors Assoc., Lexington, KY.

Niehaus, M.H., and R.C. Pickett. 1966. Heterosis and combining ability in a diallel cross in Sorghum vulgare Pers. Crop Sci. 6:33-36.

Pedersen, J.F., and J.J. Toy. 1997. Registration of 29 forage sorghum genetic stocks in $\mathrm{A}_{3}$ cytoplasm. Crop Sci. 37:1408-1409. 
Pedersen, J.F., J.J. Toy, and B. Johnson. 1998. Natural outcrossing of sorghum and sudangrass in the central Great Plains. Crop Sci. 38:937-939.

Quinby, J.R. 1963. Manifestations of hybrid vigor in sorghum. Crop Sci. 3:288-291.

Rooney, W.L. 2000. Genetics and cytogenetics. p. 261-307. In C.W. Smith and R.A. Frederiksen (ed.) Sorghum: Origin, history, technology, and production. John Wiley \& Sons, New York.

Rooney, W.L., J. Blumenthal, B. Bean, and J.E. Mullet. 2007. Designing sorghum as a dedicated bioenergy feedstock. Biofuels, Bioproducts, and Biorefining 1:147-157.
Selvi, B., and S. Palanisamy. 1987. Heterosis for stem sugar and related characters in sorghum. Ind. J. Agric. Sci. 57:423-424.

Shertz, K.F., and L.G. Dalton. 1980. Sorghum. p. 577-588. In W.R. Fehr and H.H. Hadley. (ed.) Hybridization of crop plants. ASA and CSSA, Madison, WI.

Torres-Cardona, S., A. Sotomayor-Rios, A. Quiles Belen, and K.F. Schertz. 1990. Fertility restoration to $A_{1}, A_{2}$, and $A_{3}$ cytoplasm systems of converted sorghum lines. MP-1721. Texas Agric. Exp. Stn., Texas A\&M Univ., College Station.

Vanderlip, R.L. 1993. How a sorghum plant develops. Coop. Ext. Serv. Contrib. 1203. Kansas Agric. Exp. Stn., Manhattan. 